\title{
Effect of Nebulized Suctioning with 3\% Hypertonic Saline for Mechanically Ventilated Patient on Airway Clearance
}

\author{
Dr. Metilda Phd(N)* , Dr. Jaganath MBBS,DA,DNB** \\ *Asso Nursing superintendent cum Asso. Quality manager, **Asso. Prof. in Ansthesia department \\ (PES Institute of Medical Science and research Kuppam,Andhra Pradesh)
}

\begin{abstract}
:
\section{Background:}

Mechanical ventilation is an important life-saving technology. There are a number of related problems that contribute to the morbidity and mortality of patients receiving mechanical ventilation in intensive care unit. Therefore, it became vital to use the safest and most effective method of ventilation for the shortest possible duration. Hypertonic saline Nebulized suctioning has been used to strengthen lung clearance and reduce infection in intubated patients.
\end{abstract}

\section{$>$ Methods:}

Quantitative evaluative approach of one group pretest posttest design was used to test the effectiveness of $3 \%$ hypertonic saline nebulized suctioning on airway clearance. Patients were selected by convenience sampling technique and sample consists of 30 mechanical ventilated patients in ICU PESIMSR at Andhra Pradesh. Semi structured interview schedule and modified bio- physiological parameters with arterial blood gas analysis scale were used. The level of airway clearance were recorded before and after administration of $3 \%$ hypertonic saline nebulized suctioning. Descriptive and Inferential statistics were used to investigate data collected in terms of policies.

\section{$>$ Results:}

The analysis exhibits that, there was significant difference in mean value between pretest $(7.96 \pm 2.93)$ and posttest $(2.74+2.93)$. paried ' $t$ ' calculated value was 8.46 greater than the table value, known to that there is an effectiveness of $3 \%$ hypertonic saline nebulisation on airway clearance among the patients connected with mechanical ventilator. The study suggests that the significant relationship between the post tests score with their selected demographic and clinical variables like gender, patient positioning during suctioning.

\section{Conclusion:}

The study has shown that hypertonic saline nebulization is the cheap, safe, effective and easy way to maintain the airway patency of patients connected to artificial airway.
Keywords:- Hypertonic Saline Nebulized Suctioning, Mechanical Ventilation, Airway Clearance.

\section{INTRODUCTION}

"Prevention of disease in today is one of the most important issues in human effort."

Mechanical ventilation is one of the most common interventions in the ICU. It is a supportive intervention used until the basic problem of patient is resolved. A ventilator, or respirator, is a breathing machine that helps patient's breath when they are too sick to breathe on their own. The patient is connected to the ventilator via an endotracheal tube (a flexible plastic tube that is inserted into the mouth and then lowered into the trachea).

Mechanically ventilated patients may also have airway obstruction due to variety of conditions, including weakened expiratory muscles, ineffective cough, and decreased mucociliary function. This could lead to blockage of airway secretions, which may be especially tenacious due to conservative fluid management. Reducing the time of mechanical ventilation is a common ICU goal, because prolonged ventilation is associated with an increase in morbidity and mortality.

Airway management includes specific methods to validate the patent pathway between a patient's lungs and the external environment. A blocked airway means that there may be very less oxygen in the body. Humidification, nebulization and suctioning are three important steps for airway remodeling.

Airway clearance strategies (ACTs) have the potential to improve mucociliary removal through decreased mucous membranes and improve the elimination of secretions, as well as inflammatory cells and micro organ. In general; nebulization is performed using a prescribed medication to promote suctioning of secretions. However, addition of Nebulized hypertonic saline suctioning(HSS) has been shown to activate the effect of mucociliary removal with the help of reducing viscosity of mucus secretion, stimulating cilial pulse, and reducing airway edema and increasing its hydration there through secretion it's free. Hypertonic Saline Nebulized Suctioning is a concept to improve airway clearance and reduce the length of mechanical air flow, reducing the medical difficulty of an mechanically ventilated patient. 


\section{$>$ Need for the Study}

An increase in number of critically ill patients diagnosed in the year 2015 revealed that 4,312 patients were admitted in 300 intensive care units (ICUs) in 35 countries and more than half of patients 55\% were mechanical ventilation during ICU admission (Lancê̂A Patak, etal, 2015). Therefore, it becomes the responsibility of the members of the health care team to develop a safe and patented approach for patients with mechanical ventilator to prevent complication.

\section{$>$ Objectives of the Study}

- To assess the level of airway clearance among patients with mechanical ventilator.

- To evaluate the effectiveness of 3\%hypertonic saline nebulization suctioning on airway clearance among patients connected with mechanical ventilator.

- To find out the association between post test score on $3 \%$ hypertonic saline nebulization suctioning on airway clearance between patients connected with mechanical ventilator on selected socio demographic variables and clinical variables.

\section{MATRIALS AND METHODOLOGY}

Quantitative evaluative approach of one group pretest posttest design was used for the study to determine the effectiveness of $3 \%$ nebulized suctioning with hypertonic saline on airway clearance. The study was conducted in a ICU of PES Institute of Medical Science and research Kuppam,at Andhra Pradesh after obtaining necessary permits and moral clearance. Participants who completed the sampling criteria were selected by convenience sampling technique and sample contained of 30 patients with mechanically ventilated in ICU PESIMSR.

\section{Tool Selection and Development:}

Semi structured interview schedule and modified biophysiological parameters with arterial blood gas analysis scale was used. Tool consists of three sections.

- Section A: Contains an interview schedule for collecting socio-Demographic Variables

- Section B: Consist of interview schedule for collecting Clinical variables.

- Section C: Modified bio-physiological parameters with arterial blood gas analysis scale: The modified biophysiological parameters with arterial blood gas analysis scale consisting of 7 items with a total score of 14.
Scoring for the modified bio-physiological parameters with arterial blood gas analysis scale:

\begin{tabular}{|c|c|}
\hline Score & Level of airway Interpretation \\
\hline $\mathbf{0}$ & Normal \\
$\mathbf{1 - 4}$ & Mild \\
$\mathbf{5 - 1 0}$ & Moderate \\
$\mathbf{1 1 - 1 4}$ & Severe \\
\hline
\end{tabular}

Table 1

The final draft of modified bio- physiological parameters with arterial blood gas analysis scale was prepared after testing the reliability and validity.

\section{Data collection Procedure:}

Following pretest, the experimental group received nebulization in the endotracheal tube using a nebulizer kit for $10-15$ minutes with $2 \mathrm{ml}$ of $3 \%$ hypertonic saline, with a break of two times daily for three days. With pursued by endotracheal (ET) suctioning were performed approximately 10 to 20 seconds for a period of 2 hours at a time. Posttest was carried about 15 to 20 minutes after the procedure. Bio-physiological parameters measurements were obtained from a continuous hemodynamic monitor and reports ABG. Collected data was analyzed using descriptive (frequency distribution, mean and standard deviations) and inferential calculations (chi square test, paired test).

\section{RESULTS/DISCUSSION}

With regard to demographic profile majority of data falls, on subject of age, 10(33\%) of the patient age were between $41-50$ years, $17(57 \%)$ patients were male, in accordance to education status 16(53\%) of them had primary education, the data on education $8(27 \%)$ of them were private employee, $18(60 \%)$ of them were Hindu, regarding income $12(40 \%)$ of them were earning 70009999 and marital status $24(80 \%)$ of them were married, In narrating the type of family, among the patients $12(40 \%)$ of them were belongs to nuclear family, 16(53\%) of them were vegetarian. In addition to the distribution of clinical variable majority of data falls, distribution of patients according to history of chronic illness, $16(53 \%)$ of them had history of chronic disease and Reason for mechanical ventilation $14(46 \%)$ of them had renal disorder It is verified that to frequency of suctioning $13(43 \%)$ of them were suctioning every 2 hours and duration of mechanical ventilation $19(63 \%)$ of them were in mechanical ventilation in less than 21 days, concern to patient position during suctioning $18(60 \%)$ of them were in supine position frequency of nebulisation, among the patients $15(50 \%)$ of them were had nebulisation once a day. 
Percentage distribution of Pre and Post test Level of airway clearance

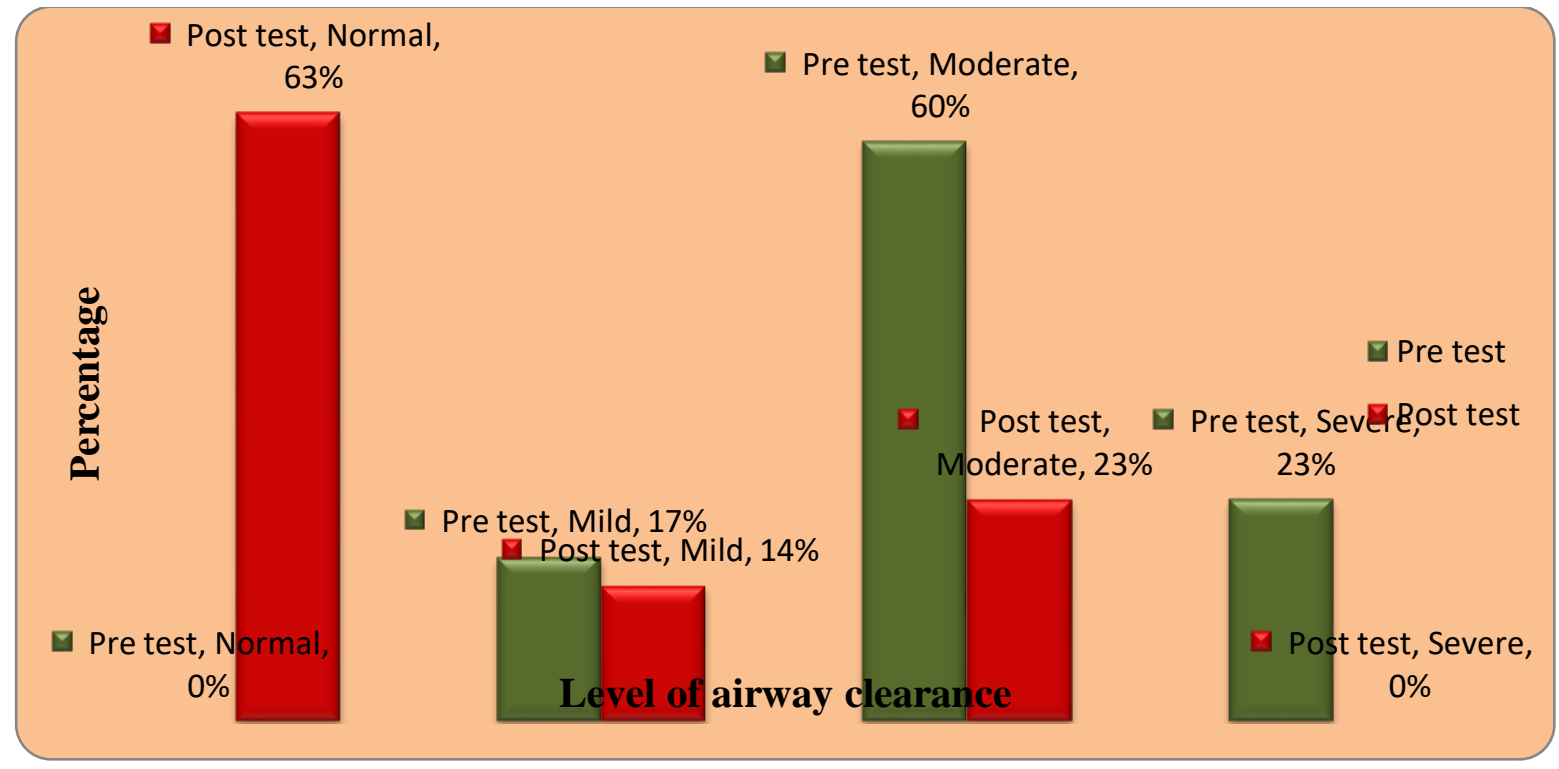

Fig 1

Figure represent the level of airway clearance, In pre $\left(0_{1)}\right.$ and $\operatorname{post}\left(0_{2)}\right.$ test among 30 patient $5(17 \%) 0_{1}, 4(14 \%) 0_{2}$ of them had mild level, $18(60 \%) 0_{1}, 7(23 \%) 0_{2}$ of them had moderate level, $7(23 \%) 0_{1}, 0 \%_{2}$ of them had severe level and $0 \% 01,19(63 \%) 0_{2}$, of them in normal level.

Mean and standard deviation with pre and post test level of airway clearance among the patients connected to mechanical ventilator

\begin{tabular}{|c|c|c|c|c|c|}
\hline S. No. & Test & Mean & SD & 't' & Table value \\
\hline 1 & Pre test & 7.96 & 3.34 & \multirow{2}{*}{$8.46^{* *}$} & \multirow{2}{*}{1.96} \\
\hline 2 & Post test & 2.74 & 2.93 & \\
\hline
\end{tabular}

$* * \mathbf{p}<0.01$

Table 2

The calculated value of $\mathrm{t}$ was 8.46 which greater than table value, it is noted that there was a highly significant between pre and post test score.

Comparison of biophysiological parameters between pretest and post test. $(N=30)$

\begin{tabular}{|c|c|c|c|c|}
\hline $\begin{array}{c}\text { Bio physiological } \\
\text { parameters }\end{array}$ & Duration & Mean & SD & $\begin{array}{c}\text { Paried 't' value } \\
\text { P value } \\
\end{array}$ \\
\hline \multirow[t]{2}{*}{ Heart rate } & Pre test & 110 & 12.354 & \multirow{2}{*}{$\begin{array}{c}1.734 \\
0.092(\mathrm{NS}) \\
\end{array}$} \\
\hline & Post test & 101 & 8.231 & \\
\hline \multirow[t]{2}{*}{ Spo2 } & Pre test & 97.01 & 1.927 & \multirow{2}{*}{$\begin{array}{c}2.934 \\
0.007 * * * \\
\end{array}$} \\
\hline & Post test & 98.83 & 1.654 & \\
\hline \multirow[t]{2}{*}{ ETCO2 } & Pre test & 48.91 & 5.320 & \multirow{2}{*}{$\begin{array}{c}1.018 \\
3.122(\mathrm{NS})\end{array}$} \\
\hline & Post test & 46.23 & 4.123 & \\
\hline \multirow[t]{2}{*}{ ABG-pH } & Pre test & 8.195 & 0.115 & \multirow{2}{*}{$\begin{array}{c}1.458 \\
0.156(\mathrm{NS})\end{array}$} \\
\hline & Post test & 8.223 & 0.117 & \\
\hline \multirow[t]{2}{*}{ ABG-PCO2 } & Pre test & 49.564 & 5.90 & \multirow{2}{*}{$\begin{array}{c}1.198 \\
0.533(\mathrm{NS})\end{array}$} \\
\hline & Post test & 55.765 & 10.532 & \\
\hline \multirow[t]{2}{*}{ ABG-PO2 } & Pre test & 84.876 & 9.65 & \multirow{2}{*}{$\begin{array}{c}2.653 \\
0.015^{*}\end{array}$} \\
\hline & Post test & 93.402 & 7.546 & \\
\hline \multirow[t]{2}{*}{ ABG-HCO3 } & Pre test & 21.76 & 6.003 & \multirow{2}{*}{$\begin{array}{c}0.076 \\
0.565(\mathrm{NS}) \\
\end{array}$} \\
\hline & Post test & 24.01 & 5.654 & \\
\hline
\end{tabular}

NS=Non significant

${ }^{*} \mathbf{p}<0.05 * * p<0.01$

Table 3 
Data comparison within the study group showed statistically significant difference in the mean value of heart rate (pretest: 110; posttest: 101 at $\mathrm{p}<0.001$ ); $\mathrm{SpO} 2$ (pretest : 97.01; posttest : 98.83 at p<0.001); ABGpH (pretest:48.91; posttest: 46.23 at p<0.01); Specialization of ABG-PCO2pretest: 49.564; posttest: 55.765 at $\mathrm{p}<0.01$ ); Optional ABGPO2 pretest:84.876; posttest:93.402 at p< 0.01);ABG-HCO3-(Pretest: 21.76; posttest: 24.01 at $\mathrm{p}<0.001)$.

Association between Post test Level of Airway Clearance with Selected Demographic \& Clinical Variables among the Patients Connected to Mechanical Ventilator

\begin{tabular}{|c|c|c|c|c|c|c|}
\hline \multirow{2}{*}{$\begin{array}{l}\text { S. } \\
\text { No. }\end{array}$} & \multirow{2}{*}{$\begin{array}{c}\text { Demographic variables / Clinical } \\
\text { variable }\end{array}$} & \multirow{2}{*}{$\mathbf{N}$} & \multicolumn{3}{|c|}{ Level of airway interpretation } & \multirow{2}{*}{ Chi square } \\
\hline & & & Normal & Mild & Moderate & \\
\hline 1 & $\begin{array}{l}\text { age in years } \\
\text { (1.1) } 21-30 \text { yrs } \\
(1.2) 31-40 \text { Yrs } \\
\text { (1.3) } 41-50 \text { Yrs } \\
\text { (1.4) } 51-60 \text { Yrs }\end{array}$ & $\begin{array}{c}4 \\
8 \\
10 \\
8\end{array}$ & $\begin{array}{l}2 \\
4 \\
9 \\
1 \\
\end{array}$ & $\begin{array}{l}1 \\
2 \\
1 \\
-\end{array}$ & $\begin{array}{l}1 \\
2 \\
- \\
4\end{array}$ & $\begin{array}{c}6.11 \\
\mathrm{Df}=6, \mathrm{NS}\end{array}$ \\
\hline 2 & $\begin{array}{c}\text { Gender } \\
\text { (2.1) Male } \\
\text { (2.2) Female }\end{array}$ & $\begin{array}{l}17 \\
13\end{array}$ & $\begin{array}{c}8 \\
11\end{array}$ & $\begin{array}{l}2 \\
2\end{array}$ & $\begin{array}{l}7 \\
-\end{array}$ & $\begin{array}{c}6.46 \\
\mathrm{Df}=2, \mathrm{~S}\end{array}$ \\
\hline 3 & $\begin{array}{l}\text { Occupational status } \\
\text { (3.1)Business } \\
\text { (3.2)Daily wages } \\
\text { (3.3) Unemployed } \\
\text { (3.4) Private } \\
\text { (3.5)Government }\end{array}$ & $\begin{array}{l}5 \\
8 \\
6 \\
8 \\
3\end{array}$ & $\begin{array}{l}4 \\
3 \\
3 \\
6 \\
3\end{array}$ & $\begin{array}{l}1 \\
2 \\
1 \\
- \\
-\end{array}$ & $\begin{array}{l}- \\
3 \\
2 \\
2 \\
-\end{array}$ & $\begin{array}{c}8.56 \\
\mathrm{Df}=6, \mathrm{NS}\end{array}$ \\
\hline 4 & $\begin{array}{c}\text { Income } \\
\text { (4.1)Rs. < 1,000 } \\
\text { (4.2)Rs. } 1000-\text { Rs. } 3999 \\
\text { (4.3)Rs. } 4000-\text { Rs. } 6999 \\
\text { (4.4)Rs. } 7000-\text { Rs. } 9999 \\
\text { (4.5)Rs. }>10000 \\
\end{array}$ & $\begin{array}{c}- \\
2 \\
8 \\
12 \\
8\end{array}$ & $\begin{array}{l}- \\
1 \\
6 \\
6 \\
6 \\
\end{array}$ & $\begin{array}{l}- \\
1 \\
2 \\
1 \\
-\end{array}$ & $\begin{array}{l}- \\
- \\
- \\
5 \\
2\end{array}$ & $\begin{array}{c}6.53 \\
\mathrm{Df}=8, \mathrm{NS}\end{array}$ \\
\hline 5 & $\begin{array}{c}\text { Type of family } \\
\text { (5.1) Nuclear family } \\
\text { (5.2) Joint family } \\
\text { (5.3) Extended family }\end{array}$ & $\begin{array}{c}12 \\
10 \\
8\end{array}$ & $\begin{array}{l}6 \\
5 \\
8 \\
\end{array}$ & $\begin{array}{l}1 \\
3 \\
- \\
\end{array}$ & $\begin{array}{l}5 \\
2 \\
- \\
\end{array}$ & $\begin{array}{c}6.74 \\
\mathrm{Df}=4, \mathrm{NS}\end{array}$ \\
\hline 6 & $\begin{array}{l}\text { Dietary pattern } \\
\text { (6.1) Vegetarian } \\
\text { (6.2) Non vegetarian }\end{array}$ & $\begin{array}{l}16 \\
14\end{array}$ & $\begin{array}{c}10 \\
9\end{array}$ & $\begin{array}{l}4 \\
-\end{array}$ & $\begin{array}{l}2 \\
5\end{array}$ & $\begin{array}{c}6.784 \\
\mathrm{Df}=4, \mathrm{NS}\end{array}$ \\
\hline 7 & $\begin{array}{l}\text { Personal habits } \\
\text { (7.1) Alcohol } \\
\text { (7.2) Smoking } \\
\text { (7.3) Tobacco chewing } \\
\text { (7.4) No bad habits }\end{array}$ & $\begin{array}{c}2 \\
10 \\
-s \\
18\end{array}$ & $\begin{array}{c}1 \\
5 \\
- \\
13\end{array}$ & $\begin{array}{l}- \\
3 \\
- \\
1\end{array}$ & $\begin{array}{l}1 \\
2 \\
- \\
4\end{array}$ & $\begin{array}{c}8.43 \\
\mathrm{Df}=8 \mathrm{NS}\end{array}$ \\
\hline 8 & $\begin{array}{l}\text { 13) Reason for mechanical ventilation } \\
\text { (8.1) CNS Disorder } \\
\text { (8.2) Cardiac Disorder } \\
\text { (8.3) Renal Disorder } \\
\text { (8.4) Metabolic disorder }\end{array}$ & $\begin{array}{c}6 \\
8 \\
14 \\
2\end{array}$ & $\begin{array}{c}3 \\
5 \\
11 \\
-\end{array}$ & $\begin{array}{l}1 \\
2 \\
- \\
1\end{array}$ & $\begin{array}{l}2 \\
1 \\
3 \\
1\end{array}$ & $\begin{array}{c}6.53 \\
\mathrm{Df}=8, \mathrm{NS}\end{array}$ \\
\hline 9 & $\begin{array}{l}\text { 14) Frequency of suctioning } \\
(9.1) \text { Every } 2^{\text {nd }} \text { hourly once } \\
(9.2) \text { Every } 4^{\text {th }} \text { hourly once } \\
(9.3) \text { Every } 6^{\text {th }} \text { hourly once }\end{array}$ & $\begin{array}{l}13 \\
8 \\
9\end{array}$ & $\begin{array}{l}8 \\
5 \\
6\end{array}$ & $\begin{array}{l}3 \\
1 \\
-\end{array}$ & $\begin{array}{l}2 \\
2 \\
3\end{array}$ & $\begin{array}{c}4.56 \\
\mathrm{Df}=4, \mathrm{NS}\end{array}$ \\
\hline 10 & $\begin{array}{l}\text { 15) Duration of mechanical } \\
\text { ventilation } \\
\text { (10.1) One week } \\
\text { (10.2) One month } \\
\text { (10.3) More than one month }\end{array}$ & $\begin{array}{c}3 \\
22 \\
5\end{array}$ & $\begin{array}{c}2 \\
16 \\
1\end{array}$ & $\begin{array}{l}1 \\
2 \\
1\end{array}$ & $\begin{array}{l}- \\
4 \\
3\end{array}$ & $\begin{array}{c}3.14 \\
\mathrm{Df}=2, \mathrm{NS}\end{array}$ \\
\hline
\end{tabular}


ISSN No:-2456-2165

\begin{tabular}{|c|c|c|c|c|c|c|}
\hline 11 & $\begin{array}{l}\text { 16) Patient Position during } \\
\text { suctioning } \\
\text { (11.1) supine position } \\
\text { (11.2)semi-Fowler's position }\end{array}$ & $\begin{array}{l}18 \\
12\end{array}$ & $\begin{array}{c}11 \\
8\end{array}$ & $\begin{array}{l}3 \\
1\end{array}$ & $\begin{array}{l}4 \\
3\end{array}$ & $\begin{array}{c}6.57 \\
D f=2, S\end{array}$ \\
\hline 12 & $\begin{array}{c}\text { Frequency of 533ebulization } \\
\text { (12.1) once a day } \\
\text { (12.2) two times a day } \\
\text { (12.3) three times a day } \\
\text { (12.4) four times a day }\end{array}$ & $\begin{array}{l}15 \\
6 \\
9 \\
-\end{array}$ & $\begin{array}{l}10 \\
3 \\
6 \\
-\end{array}$ & $\begin{array}{l}2 \\
1 \\
1 \\
-\end{array}$ & $\begin{array}{l}3 \\
2 \\
2 \\
- \\
\end{array}$ & $\begin{array}{c}8.53 \\
\mathrm{Df}=6, \mathrm{NS}\end{array}$ \\
\hline 13 & $\begin{array}{l}\text { Type of mucous secretion } \\
\text { (13.1) thicking secretion } \\
\text { (13.2) mild secretion } \\
\text { (13.3) clear secretion }\end{array}$ & $\begin{array}{c}.14 \\
13 \\
3\end{array}$ & $\begin{array}{c}12 \\
7 \\
-\end{array}$ & $\begin{array}{l}2 \\
1 \\
1\end{array}$ & $\begin{array}{l}- \\
5 \\
2\end{array}$ & $\begin{array}{c}8.74 \\
\mathrm{Df}=6, \mathrm{NS}\end{array}$ \\
\hline
\end{tabular}

The study elicit that the significant association between the post tests score with their selected demographic and clinical variables like gender, patient positioning during suctioning.

\section{* Outcome:}

From the above findings, it is clear that the oxygen levels are enhanced by the intervention of Nebulized hypertonic saline suctioning to mechanically ventilated patient.

\section{RECOMMENDATION ON THE STUDY}

A comparative study can be conducted.

The research can be repeated in a larger sample to add to the findings.

The study can be performed using 5\% of hypertonic saline nebulized extracts among patients connected to a mechanical ventilator.

\section{REFERENCES}

[1]. Dorthy, et al., (1995), "Fundamentals of Nursing Research", (2nd Ed), USA, Jones and Bartlet Publication.

[2]. Caroline Wood. Effect of nebulized 3\% hypertonic saline in the treatment of viral bronchiolitis. Pulmonary Research, 8(1), 2008, 149-158.

[3]. Caruso \& Pedro. Saline instillation before tracheal suctioning decreases the incidence of ventilatorassociated pneumonia. Critical Care Med, 37, 2009, 3238.

[4]. Dolenska S, Dalal P \& Taylor A. Essentials of airway management.(1sted). San Francisco: Mizpah publication, 2007.

[5]. Donald EC. Preventing Ventilator-Associated Pneumonia in Adults- Sowing Seeds of Change Chest journal, 30(1), 2006, 251-260.

[6]. Donaldson HS, William D, BennettZeman LK \& Michael RK Mucus Clearance and Lung Function in Cystic Fibrosis with Hypertonic Saline. The New England Journal of Medicine, 354, 2006, 241-250.
[7]. Donaldson SH, Bennett WD, Zeman KL, Knowles MR, Tarran R, Boucher RC. Mucus clearance and lung function in cystic fibrosis with hypertonic saline. New England Journal of Medicine 2006;354(3):241e50.

[8]. Elkins MR \& Peter TP. Inhaled hypertonic saline as a therapy for cystic fibrosis. Journal Pulmonary Medicine, 12(6), 2006, 445-452.

[9]. Elkins MR, et al. A controlled trial of long term inhaled hypertonic saline in patients with cystic fibrosis. The New England Journal of Medicine 2006;354(3):229e40.

[10]. Kellett F, et al. Evaluation of nebulised hypertonic saline (7\%) as an adjunct to physiotherapy in patients with stable bronchiectasis. Respiratory Medicine 2005;99:27e31.

[11]. Robinson M, Hemming A, Regnis J, Wong A, Bailey $\mathrm{D}$, Bautovich $\mathrm{G}$, et al. Effect of increasing doses of hypertonic saline on mucociliary clearance in patients with cystic fibrosis. Thorax 1997; 52:900e3 